\title{
Sosyal Bilgiler Öğretmenlerinin 8. Sınıf T.C. İnkılap Tarihi ve Atatürkçülük Ders Kitabıyla İlgili Görüşlerinin Değerlendirilmesi ${ }^{1}$
}

\author{
DOI: $10.26466 /$ opus.477153 \\ Özkan Ginesar ${ }^{*}$ - Cemal Güven ${ }^{* *}$ \\ * Öğretmen, M.E.B. Darıcı Ortaokulu, Simav/Kütahya / Türkiye \\ E-Posta: oginesar@gmail.com \\ ORCID: $\underline{0000-0002-6921-1047}$ \\ ** Prof. Dr., NEÜ Ahmet Keleşoğlu Eğitim Fakültesi, Meram/Konya/Türkiye \\ E-Posta: cemalguven@gmail.com \\ ORCID: $\underline{0000-0001-5649-1273}$
}

\section{Öz}

Bu araştırmanın amacı, 2016-2017 eğitim-öğretim yılında okutulan 8. sınıf T.C. İnkılap Tarihi ve Atatürkçülük ders kitabının güçlükleri, ders kitabının eksikleri ve ders kitabının daha işlevsel hale getirilmesi amacıyla öğretmen görüşlerini değerlendirmektir. Ders kitabının daha iyi bir şekilde öğrencilerin hizmetine sunulması için öğretmenlerin görüşlerine ve önerilerine yer verilmiştir. Bu araştırmada nitel araştırma yaklaşımlarından olgubilim deseni kullanılmıştır. Veriler araştırmacı tarafından geliştirilen yarı yapılandırılmış görüşme formu kullanılarak toplanmışıtır. Görüşmeler, Kütahya ili ve ilçelerinde görev yapmakta olan 20 öğretmen ile gerçekleştirilmiştir. Yarı yapılandırılmış görüşme formunun ilk üç sorusunda ders kitabının öne çıkan güçlükleri, eksikleri, ders kitabındaki konular ve görsellerin yeterli olup olmadığ alınmıştır. Görüşme formunun son sorusunda ders kitabının daha faydalı olabilmesi için öğretmenler önerileri sorulmuştur. Elde edilen veriler içerik analiz yöntemiyle çözümlenmiştir. Öğretmen görüşleri kodlama yapılarak frekans ve yüzde tabloları oluşturulmuştur. Sosyal bilgiler öğretmenlerinin görüşleri doğrultusunda Türkiye Cumhuriyeti İnklap Tarihi ve Atatürkçülük ders kitabının daha faydalı olması için konuların kısa ve öz olması, görsellerin arttırlması, sayfaların paragrafa boğulmaması ve önemli noktaların dikkat çekici şekilde belirtilmesi şeklinde öneriler getirilmiştir.

Anahtar Kelimeler: Ortaokul, Ders Kitabı, Türkiye Cumhuriyeti İnkılap Tarihi ve Atatürkçülük.

\footnotetext{
${ }^{1}$ Bu makale Özkan Ginesar'ın "8. Sınıf T.C. Inkılap Tarihi ve Atatürkçülük Ders Kitabına Yönelik Sosyal Bilgiler Öğretmenlerinin Algı ve Tutumlarıın Belirlenmesi" adlı Yüksek Lisans Tez çalışmasından üretilmiş olup 24 Kasım 2017 tarihinde Antalya'da düzenlenen 3'üncü Uluslararası Eğitim, Uzaktan Eğitim ve Eğitim Teknolojileri Kongresi'nde sunulan "Ortaokul T.C. Inkılap Tarihi ve Atatürkşülük Ders Kitabının Öğretmen Görüşlerine Göre Değerlendirilmesi" adlı bildirinin genişletilmiş hâlidir.
}

OPUS (c) Uluslararası Toplum Araştırmaları Dergisi-International Journal of Society Researches ISSN:2528-9527 E-ISSN : 2528-9535

http://opusjournal.net 


\title{
Evaluation of Social Studies Teachers' Visions Related the 8th Grade Turkish Republic History of Revolution and Ataturkism Course Book
}

\begin{abstract}
The objective of this research is to evaluate teacher comments for the purpose of defining difficulties and deficiencies of 8th grade Turkish Republic History of Revolution and Ataturkism course book that is taught in 2016-2017 education year and bringing course book to more functional state. It was included teacher and student comments to dedicate course book to students as better. Phenomenological pattern that is a qualitative research approach was used in this study. Data were collected using semi-structured interview form developed by researcher. Interviews were performed with 20 teachers working Kutahya city and its counties. It was received teacher opinions about outstanding difficulties and deficiencies of course book, whether subjects and visuals are enough in course book in the first three questions of semi-structured interview form. It was taken suggestions from teachers for what can be done for it to be more useful in the last question of interview form. Obtained data were analyzed with content analysis method. Frequency and percentage tables were created by coding teacher comments. In the direction of social studies teachers, it was suggested that topics should be brief, pages shouldn't be choked to paragraph, and important points should remarkably be specified in order that Turkish Republic History of Revolution and Ataturkism course book is more beneficial.
\end{abstract}

Keywords: Secondary School, Course Book, Turkish Republic History of Revolution and Atatürkism. 


\section{Giriş}

Ders kitaplarının geçmişi M.Ö. 4000 yıllarına kadar dayandığı varsayılmaktadır. Bu kadar eski bir geçmişe sahip olan ders kitapları geçmişten günümüze yaşanılan çağın sosyal, kültürel ve teknolojik olarak toplumun ihtiyaçlarına uygun olarak değişim ve gelişim göstermiştir (Çakır U. , 2006). Belli bir ders programın konularının aktarıldığı öğrencilere bilgi ve becerileri kazandırmak için hazırlanan ders kitapları eski ve önemini yitirmemiş en önemli öğretim aracıdır (Uzuner, Aktaş, ve Albayrak, 2010). Ders kitapları günümüz teknoloji ve bilgi çağında da öğrenci ve öğretmenlerin doğrudan muhatap oldukları en önemli bilgi araçlarından bir tanesidir. Eğitim ve öğretim sürecinde öğretmen ve öğrencilerin en sık kullandıkları bilgi araçlarını ders kitapları oluşturmaktadır. Günümüz teknoloji çağında da ders kitapları hala önemini korumaktadır (Çakır U. , 2006). Ders kitaplarının eğitim-öğretim için önemi göz önüne alındığında ders kitaplarının seçimi önem arz etmektedir. Ders kitapları eğitim-öğretimde kullanılan en temel ve en önemli araçlardır. Aynı zamanda öğrenciyi dersin hedefleri doğrultusunda motive eden yönlendiren kitaplardır (Çakır A. , 2006). Öğretim programı ile öğrenci arasındaki iletişim araçlarından en önemlisi olan ders kitapları, öğretmenin daha etkili bir öğretim gerçekleştirmesini sağlayan temel öğretim materyalleridir (Ceylan ve Yiğit, 2004). Buna ek olarak ders kitapları hem öğrenciye hem de öğretmene öğretim süresince yol gösteren ve yardımcı olan önemli eğitim-öğretim unsurudur (Kılıç ve Seven, 2002). Öğrenciler için zengin öğrenme ortamlarının oluşturulamadığı durumlarda ders kitapları temel kaynak olarak ön plana çıkmaktadır. Ayrıca genellikle öğretmenler ders esnasında kullanacakları yöntemleri ders kitaplarına göre belirlemektedir (Çetin, 2008).

Türkiye'de ders kitapları, temel bir bilgi kaynağı olup derslerde en çok kullanılan öğretim materyallerinden birisidir (Kılıç \& Seven, 2002). Ders kitapları öğretmenin dersini daha sistematik işlemesine imkân tanır. Ders kitapları sayesinde öğrenci öğretmenin anlattıklarını istediği yerde ve istediği zaman tekrar etme imkanı bulur (Duman \& Çakmak, 2003). İlkokul ve lisede tarih ile ilgili temel davranış ve bilgiyi geliştirmede ders kitaplarının kullanımı öğrenci üzerinde olumlu etki sağlamaktadır (Wakefield, 2006). Ders kitaplarının bilişsel, duyuşsal ve 
psikomotor becerilerinin gelişiminde en önemli rol oynadığı düşünüldüğünde ilköğretim çağındaki ders kitaplarının niteliğine çok önem verilmelidir. Çünkü kaliteli bir ders kitabı ile iyi bir eğitim gerçekleşir (Uzuner, Aktaş, ve Albayrak, 2010). Eğitim-öğretime sağladığı katkılar düşünüldüğünde ders kitaplarının hazırlanma sürecinin önemi artmaktadır.

İçinde bulunduğu toplumun geçmişe ait hafızasını taze tutan, toplumların belli bir coğrafya da niçin ve nasıl yaşadığını, toplumların inançların değer ve geleneklerini aktaran en önemli materyaller tarih ders kitaplarıdır (Çakır U. , 2006). İnkılap Tarihi ve Atatürkçülük derslerinin amacı Türkiye Cumhuriyeti'nin hangi şartlarda kurulduğunu anlatabilmek ve yaşatabilmek ve kurucusu olan Mustafa Kemal Atatürk'ün ilke ve inkılaplarını tanıtarak benimsetmektir (Şimşek ve Güler, 2013). T.C. İnkılap Tarihi ve Atatürkçülük dersinin eğitim öğretimdeki yeri ve önemi ile ders kitaplarının da eğitim öğretimde en çok kullanılan eğitim aracı olması göz önüne alındığında T.C. İnkılap Tarihi ve Atatürkçülük ders kitabının önemi ortaya çıkmaktadır. Bu araştırmada sosyal bilgiler öğretmenleri tarafından ilköğretim 8. sınıf T.C. İnkılap Tarihi ve Atatürkçülük ders kitabının öne çıkan güçlükleri, eksikleri, ders kitabındaki konular ile görsellerin yeterli olup olmadığı ve daha faydalı olabilmesi için nelerin yapılması gerektiği hususunda görüş alınması amaçlanmıştır. Alınan öğretmen görüşleri doğrultusunda değerlendirmelerde ve önerilerde bulunulmuştur.

$\mathrm{Bu}$ araştırmanın amacl, 2016-2017 eğitim-öğretim yılında okutulan T.C. İnkılap Tarihi ve Atatürkçülük ders kitabına yönelik öğretmen görüşlerinin belirlenmesidir. Öğretmenlerin görüşleri doğrultusunda ders kitabının güçlükleri ve eksikleri ortaya konarak ders kitabının daha işlevsel hale gelmesi için önerilerde bulunmaktır. T.C. İnkılap Tarihi ve Atatürkçülük ders kitabına yönelik sosyal bilgiler öğretmenlerinin görüşlerini belirlemek için Kütahya merkez ve ilçelerinden seçilen 20 öğretmene 4 adet açık uçlu soru sorulmuştur. Bu açık uçlu sorular "Türkiye Cumhuriyeti Inkılap Tarihi ve Atatürkçülük ders kitabının kullanımı ile ilgili karşılaştığınız güçlükler nelerdir?", "Türkiye Cumhuriyeti İnkılap Tarihi ve Atatürkçülük ders kitabının eksik bulduğunuz yönleri var mıdır? Varsa nelerdir?", "Türkiye Cumhuriyeti Inkılap Tarihi ve Atatürkçülük ders kitabındaki konular ve görseller öğrencilerinizin dikkatini çekmekte yeterli midir? Bu ko- 
nuda neler düşünüyorsunuz?", "Türkiye Cumhuriyeti İnklap Tarihi ve Atatürkçülük ders kitabının daha faydalı olması için neler önerirsiniz?" şeklindedir.

\section{Yöntem}

$\mathrm{Bu}$ çalışmada nitel araştırma yaklaşımlarından olgubilim deseni kullanılmıştır. Olgubilim deseni,farkında olduğumuz fakat derinlemesine ve ayrıntılı bir bilgi ve anlayışa sahip olmadığımız olgulara odaklanarak farkına varmamızı sağlar. Olgubilim deseni bize tam olarak yabancı olmayan ancak tam olarak kavrayamadığımız olguları araştırmayı amaçlayan çalışmalar için kullanılan bir yöntemdir (Yıldırım ve Şimşek, 2016).

8. sınıf Türkiye Cumhuriyeti İnkılap Tarihi ve Atatürkçülük ders kitabının değerlendirilmesine yönelik yapılan görüşmelerde, daha önce aynı amaçla yapılan görüşmelerde kullanılan görüşme formları da dikkate alınarak araştırmacı tarafından yarı yapılandırılmış görüşme formu geliştirilmiştir.

\section{Veri Toplama Araçları}

Öğretmen görüşlerini belirlemek amacıyla yarı yapılandırılmış görüşme formu kullanılmıştır. Yarı yapılandırılmış görüşme formunda araştırmacı soruları görüşmeye başlamadan önce hazırlar. Buna karşın koşullara bakarak hazırlamış olduğu soruları yeniden düzenleyebilir veya bireyler ve sorulara bakarak bazı esneklikler sağlayabilir (Çepni, 2014).

\section{Araştırmanın Çalışma Grubu}

Araştırmanın çalışma grubunu Kütahya merkez ve ilçelerinden görev yapmakta olan 20 öğretmen oluşturmaktadır. Örneklemin seçiminde amaçlı örneklem yöntemlerinden maksimum çeşitlilik örneklemesi kullanılmıştır. Bu örnekleme yönteminde ortaya konulan araştırma için bireylerin çeşitliliği maksimum dereceyi yansıtmaktadır (Yıldırım ve 
Şimşek, 2016). Çalışma da Kütahya kent ve taşra merkezlerinden öğretmenler seçilmiştir. Öğretmenlerle yüz yüze görüşme yapılarak görüşme formu uygulanmıştır. Görüşmelerde öğretmenlerin gönüllü olma esasına dikkat edilmiştir.

Tablo 1: Katılımcıların Demografik Bilgilerine İlişkin Dağılımları $(n=20)$

\begin{tabular}{|c|c|c|c|}
\hline Değişken & & $f$ & $\%$ \\
\hline \multirow{2}{*}{ Cinsiyet } & Erkek & 12 & 60 \\
\hline & Kadın & 8 & 40 \\
\hline \multirow{2}{*}{ Öğrenim Durumu } & Lisans & 19 & 95 \\
\hline & Yüksek lisans & 1 & 5 \\
\hline \multirow{3}{*}{ Mesleki Unvan } & Öğretmen & 15 & 75 \\
\hline & Uzman öğretmen & 3 & 15 \\
\hline & Sözleşmeli Öğgretmen & 2 & 10 \\
\hline \multirow{4}{*}{ Yaş } & $20-28$ arast & 3 & 15 \\
\hline & 29-37 arast & 10 & 50 \\
\hline & $38-46$ arast & 5 & 25 \\
\hline & 46 ve üzeri & 2 & 10 \\
\hline \multirow{5}{*}{ Mesleki Kıdem } & $0-10$ yil & 11 & 55 \\
\hline & 11-15 yıl & 4 & 20 \\
\hline & $16-20$ yil & 2 & 10 \\
\hline & 21-25 yil & 2 & 10 \\
\hline & 21 yıl ve üzeri & 1 & 5 \\
\hline \multirow{3}{*}{$\begin{array}{l}\text { Mezun Olunan Yükseköğretim } \\
\text { Kurumu }\end{array}$} & Fen Edebiyat Fakültesi & 1 & 5 \\
\hline & Eğitim Fakültesi & 18 & 90 \\
\hline & Diğer & 1 & 5 \\
\hline
\end{tabular}

Araştırmanın çalışma grubunu 2016-2017 eğitim-öğretim yılında Kütahya merkez ve ilçelerinde görev yapan gönüllü yirmi sosyal bilgiler öğretmeni oluşturmaktadır. Öğretmenlerin demografik bilgilerine bakıldığında mülakata katılanların on ikisi erkek, sekizi kadın olup öğrenim durumu bakımından on dokuzu lisans, birisi yüksek lisans mezunudur. Öğretmenlerin mesleki unvanlarına bakıldığında on beşi öğretmen, üçü uzman öğretmen ve ikisi de sözleşmeli öğretmen olduğu görülmektedir. Öğretmenlerin yaşları incelendiğinde üçü 20-28 yaş aralığında, onu 29-37 yaş aralığında, beşi 38-46 arasında, ikisi de 46 yaş ve üzerini oluşturmaktadır. Öğretmenlerin mesleki kıdemleri ise on birinin 0-10 yıl, dördünün 11-15 yıl arasında, ikisi 16-20 yıl, üçü de 46 yıl 
üzeri çalışanlardan oluşmaktadır. Mezun olunan yükseköğretim kurumuna bakıldığında birini Fen Edebiyat Fakültesi, on sekizini Eğitim Fakültesi ve birini ise diğer yükseköğretim kurumlarından mezun olanlardan oluştuğu görülmektedir.

\section{Verilerin Toplanması}

8. sınıf Türkiye Cumhuriyeti İnkılap Tarihi ve Atatürkçülük ders kitabının değerlendirilmesine yönelik yapılan görüşmelerde, daha önce aynı amaçla yapılan görüşmelerde kullanılan mülakat formları dikkate alınarak araştırmacı tarafından yarı yapılandırılmış görüşme formu geliştirilmiştir. Görüşme formu Kütahya merkez ve kırsallarından seçilen sosyal bilgiler öğretmenlerinin okullarına gidilerek uygulanmıştır. Görüşmelerde gönüllük esası dikkate alınmıştır. Ayrıca görüşmelerde katılımcıların kimliklerinin saklı kalacağı vurgulanmıştır.

\section{Verilerin Analizi}

Açık uçlu sorulardan elde edilen verilerin analizinde içerik analiz kullanılmıştır. İçerik analizi birbirine benzeyen veriler belirli kavramlar ve temalar etrafında bir araya getirilerek okuyucunun anlayabileceği şekilde yorumlanması şeklinde ifade edilebilir. Belge incelenirken kategoriler oluşturulur. Araştırmacı nitel veriye bir dizi kodlar uygulayarak birbiriyle ilintili kod listesi (matriks) oluşturarak içerik analizi yapar (Ekiz, 2013).

Nitel verilerin sayısallaştırılması çalışmaların geçerlilik ve güvenilirliğini arttırmada etkilidir (Yıldırım ve Şimşek, 2016). Fakat nitel çalışmalarda verilen frekans ve yüzdeler nicel araştırmalardaki gibi istatistiksel karşılaştırmalar için kullanılmaz. Nitel araştırmalarda frekans ve yüzde verilmesinin amacı oluşturulan kategorilerdeki anlamları analiz edebilmek ve bu anlamları birbiri ile karşılaştırmaktır (Kesici, 2007). Bu bağlamda yarı yapılandırılmış görüşme formundaki açık uçlu sorulardan elde edilen öğretmen görüşleri kategorileştirilerek kodlamalar yapılmıştır. Maddelerden elde edilen kodların tutarlılı̆̆ını belirlemek için ikinci bir uzman araştırmacı tarafından kodlamalar kontrol 
edilmiştir. Yapılan bu araştırmada frekans ve yüzdelere yer verilmiştir. Ayrıca nitel verilerin daha ayrıntılı bir şekilde yansıtılması amaciyla da sosyal bilgiler öğretmenlerinin görüşlerinden alıntılar yapılmıştır. Araştırmada verilerin sunulmasında daha önceden öğretmenlere belirtildiği üzere öğretmen isimleri belirtilmemiştir. Örnek alıntılar yapılırken Ö1, Ö2, ..., Ö20 kodları kullanılmıştır.

\section{Bulgular}

\section{Türkiye Cumhuriyeti İnklap Tarihi ve Atatürkçülük Ders Kitabının Kullanımı İle İlgili Karşılaşılan Güçlükler}

Sosyal bilgiler öğretmenlerinden ilk olarak T.C. İnkılap Tarihi ve Atatürkçülük ders kitabının kullanımıyla ilgili olarak karşılaştıkları güçlükleri ifade etmeleri istenmiştir. Sosyal bilgiler öğretmenlerinin görüşleri Tablo 2'de kodlar halinde sunulmuştur.

Tablo-2: Sosyal Bilgiler Öğretmenlerinin Görüşleri Doğrultusunda Ders Kitabının Öne Çıkan Güçlükleri

\begin{tabular}{lll}
\hline Kodlar & $f$ & \% \\
\hline Içeriğin yoğun olması & 13 & 65 \\
Metinlerin uzun olması & 10 & 50 \\
Konuların açık, net ve anlaşılır ifade edilmeyişi & 8 & 40 \\
Öğrenci seviyesine uygun olmaması & 5 & 25 \\
Öğrencinin ilgisini çekecek şekilde hazırlanmayışı & 3 & 15 \\
Konulardaki Osmanlıca kelimelerin çokluğu & 2 & 10 \\
İçeriğin sayfalara düzenli yerleştirilmemesi & 2 & 10 \\
Konuların bir bütün içerisinde verilmeyişi & 2 & 10 \\
İçeriğin TEOG sınavına yönelik hazırlanmayışı & 2 & 10 \\
Harita, grafik ve tabloların dikkat çekici olmayışı & 1 & 5 \\
Konu ile günümüz arasında bağlantı olmayışı & 1 & 5 \\
\hline
\end{tabular}

Sosyal bilgiler öğretmenlerinden on üçü içeriğin yoğun olduğunu, onu metinlerin uzun olduğunu, sekizi de konuların açık, net ve anlaşılır bir şekilde ifade edilmediği görüşünü belirtmişlerdir. Bu durum ile ilgili bazı öğretmen görüşlerine aşağıda yer verilmiştir. 
Ö1: "Sayfalarm yazıyla, paragraflarla dolu olması dersin sıkıcı hale gelmesine neden oluyor."

Ö2: "Konular ayrıntılı anlatılmış, gerekli bilgiler fazlasıyla verilmiş ama kavramsal şemalar oluşturulmadığı için öğrenciye konu çok zor gelmektedir."

Ö9: "Konular uzun ve sıkıcı anlatılmıs. Bunun yerine kısa notlarla, neden ve sonuçlarla hazırlanmış olsaydı, sayfaların yanında bilgi kutucuklarına yer verilseydi daha iyi olurdu."

Öğretmen görüşlerine dayanılarak T.C. İnkılap Tarihi ve Atatürkçülük ders kitabından konuların ayrıntılı ve uzun anlatıldığı bununda öğrenciyi sıktığı sonucuna varılmıştır. Konuların kısa ve öz anlatılarak öğrencilerin ilgisini çekebilecek kısa bilgi kutucukları yer verylerek daha renkli bir anlatım sağlanabilir.

Sosyal bilgiler öğretmenlerinden beşi öğrenci seviyesine uygun olmadığını, öğretmenlerin üçü de öğrencinin ilgisini çekecek şekilde hazırlanmadığ şeklinde görüş beyan etmişlerdir. Bu durum ile ilgili birkaç öğretmen görüşüne aşağıda yer verilmiştir.

Ö11: "Alıntı metinlerdeki cümleler uzun ve öğrenci seviyesinin üzerinde bir dil kullanılmıştır."

Ö15: "Konular arasında bütünlük să̆lamamakta bu da öğrencinin dikkatini çekmekte yetersiz kalmasina sebep olmaktadır."

Ö${ }_{17}$ : "Ders kitabının görselliği düşüktür. Kitap öğrencilerin dikkatini ve ilgisini çekmiyor."

Sosyal bilgiler öğretmenlerin ifadelerinden de anlaşılacağı üzere ders kitabında öğrenci seviyesine uygun bir dil kullanılmalı ve öğrencinin dikkatini çekmek için ders kitapları görsel olarak zenginleştirilmelidir.

Sosyal bilgiler öğretmenlerinden ikisi konuların bir bütün içinde verilmediği, diğer ikisi içeriğin sayfalara düzenli yerleştirilmediği ve yine öğretmenlerden ikisi konulardaki Osmanlıca kelimelerin çok olduğu yönünde ve içeriğin TEOG sınavına yönelik hazırlanmadığını ifade etmişlerdir. Öğretmenlerden biri harita, grafik ve tabloların dikkat çekici olmadığ1 ve diğer biri de konu ile günümüz arasında bağlantı olmadığı 
yönünde görüşlerini belirtmişlerdir. Bu durum ile ilgili katılımcıların bazı ifadelerine aşağıda yer verilmiştir.

Ö5: "Ders kitabında karşılaştığım güçlüklerden bir tanesi konuların içindeki eski kelimelerin çokluğudur."

Ö14: "Konular bir bütünlük halinde ve kavram bilgisine yer verilerek verilmelidir."

Ö15: "Konular arasında bütünlük sağlanamamakta ve öğrencinin dikkatini çekmekte yetersiz geliyor."

Öğretmen görüşlerince konular bir bütün halinde verilmeli ve konu içerisinde eski kelimelere çok yer verilmemelidir. Konu içerisinde kavram bilgisine yer verilmeli ve sayfalara içerik düzenli yerleştirilerek öğrencinin dikkati konuya çekilmelidir.

\section{Türkiye Cumhuriyeti İnkılap Tarihi Ve Atatürkçülük Ders Kitabının Eksik Yönleri}

Sosyal bilgiler öğretmenlerine T.C. İnkılap Tarihi ve Atatürkçülük ders kitabının eksik yönlerini belirtmeleri istenmiş ve sosyal bilgiler öğretmenlerin verdikleri cevaplar Tablo 3 'te görsel olarak kodlar şeklinde, tablonun altında da öğretmen görüşlerine yer verilmiştir.

Tablo-3: Sosyal Bilgiler Öğretmenlerinin Görüşleri Doğrultusunda Ders Kitabının Eksikleri

\begin{tabular}{lll}
\hline Kodlar & $f$ & \% \\
\hline Görselliğin az olması & 7 & 35 \\
Özet bilgilerin olmayısıı & 6 & 30 \\
Yeterli sorunun olmaması & 6 & 30 \\
Akılda kalacak şekilde şifreleme, kodlama ve uyarıların & 3 & 15 \\
olmaması & & 10 \\
Anlamayı kolaylaştıracak şekilde kronolojik olmayışı & 2 & 10 \\
Sözlüğ̈̈n yeterli olmaması & 2 & 10 \\
Karikatürlerin olmaması & 2 & 10 \\
Kavram haritasının olmayışı & 2 & 5 \\
Neden-Sonuç ilişkisinin olmayışı & 1 & \\
\hline
\end{tabular}


Sosyal bilgiler öğretmenlerinin yedisi görselliğin az olduğunu, altısı özet bilgilerin olmadığını ve beş öğretmen de yeterli sorunun sorulmadığını belirtmişlerdir. Bu durumla ilgili olarak sosyal bilgiler öğretmenlerinin ifadelerinden bir kaçı aşağıda verilmiştir.

Ö̈: “T.C. İnkılap Tarihi ve Atatürkçülük ders kitabının daha görsel hale dönüştürülmesi gerekiyor. Daha kısa özet bilgiler verilerek görseller arttırılmalıdır."

$\ddot{O}_{4}$ : "Öğrenciler görsellerle zenginleştirilen konuları daha iyi anlarken, görsel olmayan konular zihinde soyut kaldiğı için öğrenci konuyu somutlaştıramıyor."

Ö6: "Ünite sonlarında sorular yetersiz kalmaktadır."

Sosyal bilgiler öğretmenlerinden üçü akılda kalacak şifreleme, kodlama ve uyarıların olmadığını, ikisi anlamayı kolaylaştıracak kronolojinin olmadığını ve yine ikisi de kavram haritasının olmadığ 1 yönünde görüş beyan etmişlerdir. Bu görüşlerden üu̧üne aşağıda yer verilmiştir.

$\ddot{O}_{4}$ : "Ders kitabında anlamayı kolaylaştıracak kronolojilere yer verilmeli, önemli şeylerin şifrelemeleri ve kodlamaları kitapta yer almalıdır."

Ö$_{10}$ : "Konularda şifreleme, not ve uyarlara yer verilerek öğrencinin ilgisi çekilmelidir."

Ö17: "Anahtar kelimeler ve kodlamalar gibi akılda kalıci teknikler kullanılarak öğrenme kahıcı hale getirilebilir ve bu sayede öğrenme kolaylaştırılmış olur."

Sosyal bilgiler öğretmenlerinin ifadelerinden yola çıkarak T.C. İnkılap Tarihi ve Atatürkçülük ders kitaplarının içeriği anlamayı kolaylaştıracak kronolojide olmalı, konu aralarında şifreleme, not ve uyarılar verilerek öğrencinin dikkati çekilmelidir.

Sosyal bilgiler öğretmenlerinden iki kişi sözlüğün yeterli olmadığını, iki kişi kitapta karikatürlerin bulunmadığını ve birisi konularda nedensonuç ilişkisinin olmadığı yönünde görüşlerini belirtmişlerdir. Bu durum ile ilgili öğretmen görüşlerine aşağıda yer verilmiştir. 
Ö1: "Konuyla ilgili fotoğrafların dışında görsel olarak karikatürlerde kullanılmalıdır."

Ö:: "Aktarllan konular günümüz Türkiye'si ile ilişki kurularak anlatılarak öğrenme kahıc hale getirilebilir."

Ög: "Konular uzun ve sıkıcı anlatılmış. Bunun yerine kısa notlarla ve neden sonuç ilişkisi içinde konular anlatılmalıdır."

T.C. İnkılap Tarihi ve Atatürkçülük ders kitaplarında konuyla ilgili karikatürlere yer verilmeli, konular daha kısa anlatılmalı, konu aralarına dikkat çekici notlar verilmeli ve günümüzle bağlantı kurularak öğrencinin konuya motive olması sağlanmalıdır.

Türkiye Cumhuriyeti İnkılap Tarihi ve Atatürkçülük ders kitabındaki konular ve görseller öğrencilerimizin dikkatini çekmekte yeterli midir?

Sosyal bilgiler öğretmenlerine T.C. İnkılap Tarihi ve Atatürkçülük ders kitabındaki konular ve görsellerin yeterli olup olmadığı sorulmuştur. Öğretmenlerin büyük çoğunluğu yetersiz bulurken ikisi yeterli olduğunu ifade etmiştir. Öğretmenlerin verdiği cevaplar Tablo-4'te kodlar şeklinde sunulmuştur.

Tablo-4: Ders Kitabındaki Konular ve Görsellerin Yeterli Olup Olmadı̆̆ı Hakkında Sosyal Bilgiler Öğretmenlerinin Görüşleri

\begin{tabular}{lll}
\hline Kodlar & $\boldsymbol{F}$ & $\%$ \\
\hline Konular ve görseller öğrencinin dikkatini çekmekte yeterli & 2 & 10 \\
Konular ve görseller öğrencinin dikkatini çekmekte yeterli değil & 18 & 90 \\
\hline
\end{tabular}

Elde edilen veriler Tablo 4'te kodlanmış aşağıda ise öğretmenlerin ifadelerine yer verilmiştir. Öğretmenlerden ikisi konular ve görseller öğrencinin dikkatini çekmekte yeterli olduğu görüşünü belirtmiştir. Bu görüşler şu şekildedir:

$\ddot{O}_{2:}$ "Ders kitabında yer alan görseller öğrencilerin dikkatini çekecek nitelikte ama sözel anlatımın öğrencilere fazla geldiğini düşünüyorum. Ders kitabın eleştirmekten ziyade ders saatinin süresi arttırlmalıdır." 
Ö19: "Yeterlidir. Merkezi smavlara yönelik çalışma yapan öğrencilere yeterli geldiğini düşünüyorum."

Sosyal bilgiler öğretmenlerinden ikisi görsellerin öğrenci dikkatini çekmekte yeterli olduğunu ancak sözlü anlatım fazla olduğu için ders saatinin yetersiz olduğunu ifade etmişlerdir.

Öğretmenlerden geriye kalan on sekiz kişi konular ve görsellerin öğrencinin dikkatini çekmekte yeterli olmadığını belirtmiştir. Bu görüşlerin birkaçına aşağıda yer verilmiştir.

Ö3: "Hayır yeterli değildir. Daha görsel hale dönüştürülmesi gerekiyor. Konu anlatımlar daha öz ve az bilgi ile sunulmahdır. Mevcut haliyle öğrenciler zorlaniyor."

Ö8: "Kesinlikle yeterli değildir. Kullanılan görsellerin bazıları konu ile alakasızdır. Daha detaylı ve geniş bir çalışmayla yeni ve özgün fotoğraflar kullanılarak öğrencilerin ilgisi çekilebilir."

$\ddot{O}_{17:}$ "Kitap öğrenciler tarafindan dikkat çekici bulunmuyor. Tablo, grafik, fotoğraf, resim vb. görsellere daha fazla yer verilirse daha ilgi çekici olabilir."

Sosyal bilgiler öğretmenlerinin görüşleri doğrultusunda T.C. İnkılap Tarihi ve Atatürkçülük ders kitaplarında görseller daha fazla, konular kısa ve öz olmalı, konuyla ilgili görsellerin kullanımına özen gösterilmeli ve tablo, resim ve grafiklere daha çok yer verilerek öğrencinin ilgisi çekilmelidir.

\section{Türkiye Cumhuriyeti Inkılap Tarihi ve Atatürkçülük Ders Kitabının Daha Faydalı Olabilmesi İçin Neler Önerirsiniz?}

Sosyal bilgiler öğretmenlerinden T.C. İnkılap Tarihi ve Atatürkçülük ders kitabının daha faydalı olması için önerilerde bulunmaları istenmiş ve öğretmenlerin görüşleri Tablo 5'te kodlanarak sunulmuştur.

T.C. İnkılap Tarihi ve Atatürkçülük ders kitabı ile ilgili olarak sosyal bilgiler öğretmenlerinin on üçü konuların kısa ve öz olması gerektiğini, öğretmenlerin yedisi görsellerin arttırılması, altısı paragraflara boğulmaması gerektiğini ifade etmişlerdir. Öğretmenlerden dördü de önemli noktaların farklı renklerle, şekillerle ve uyarılarla belirtilmesi gerektiğini 
ifade etmişlerdir. Bu durumla ilgili öğretmen görüşlerinden birkaçna aşağıda yer verilmiştir.

Tablo-5: T.C. Inkılap Tarihi ve Atatürkçülük Ders Kitabının Daha Faydalı Olması İçin Sosyal Bilgiler Öğretmenlerinin Görüş̧leri

\begin{tabular}{lll}
\hline Kodlar & $f$ & $\%$ \\
\hline Konular kısa ve öz olmalı & 13 & 65 \\
Görseller arttırılmalı & 6 & 30 \\
Sayfalar paragraflara boğulmamalı & 6 & 30 \\
Önemli noktalar farklı renkler, şekiller ve uyarılarla belirtilmeli & 4 & 20 \\
Şifrelemeler ve kodlamalar olmalı & 3 & 15 \\
Konuların sonunda özet kısım olmalı & 3 & 15 \\
Etkinlik sayısı arttırılmalı & 3 & 15 \\
Değerlendirme soruları arttırılmalı & 2 & 10 \\
Ünite sonu sözlükleri eklenmeli & 2 & 10 \\
Konulara ait liste ve tablolar eklenmeli & 2 & 10 \\
Eski ve yeni olaylar karşılaştırılmalı olarak verilmelidir & 2 & 10 \\
Kitap konuların bölündü̈̈̈ fasiküller şeklinde hazırlanmalıdır & 1 & 5 \\
\hline
\end{tabular}

Ö1: “Görseller arttırılmalı, sayfalar paragrafa boğulmamalıdır. Önemli Iffadeler farklı renk ve şekillerle belirtilmelidir."

Ö9: "Konular destan gibi uzun olmak yerine kısa ve net anlatılmalıdır. Paragraf yerine kısa maddeler şeklinde konular verilmelidir. Sayfalarm yanlarına bilgi kutucukları konulmalıdır. Daha canlı renkler ve fotoğraflar kullanılabilir."

Ö12: "Kitabın gereksiz ayrıntılardan kaçması lazım. Benzer cümleler sıkça kullanılmıştır. Bir konunun ayrıntıları veya özeti maddeleştirilerek verilebilir. Konunun veya ünitenin sonunda özet veya sonuç kısmının olması gerekmektedir."

T.C. İnkılap Tarihi ve Atatürkçülük ders kitabında konular uzun anlatılmamalı, gereksiz ayrıntılara yer verilmemeli ve görsel olarak zenginleştirilmelidir. Sayfalar paragraflara boğulmamalı, önemli noktalar farklı renk ve şekiller ile belirtilerek öğrencinin dikkatinin dağılmasının önüne geçilmelidir. Öğrencilerin dikkatini çekecek bilgi kutucuklarına yer verilmeli ve ünite sonlarına özet kısmı eklenmelidir.

Sosyal bilgiler öğretmenlerinden üçü şifreleme ve kodlamaların olması, üçü konuların sonunda özet veya sonuç kısmının yer alması ve yine diğerlerinden üçü de etkinlik sayısının artması gerektiği yönünde 
görüş beyan etmişlerdir. Bu durumla ilgili birkaç ifadeye aşağıda yer verilmiştir.

Ö12: "Bir konunun ayrnntılarn veya özeti maddeleştirilerek verilmelidir. Konuların veya ünitenin sonunda özet veya sonuç kısmının olması gerekmektedir."

Ö13: "Ünite sonlarnna kısa özetler eklenebilir."

Ö15: "Etkinliklere daha fazla yer verilmeli, öğrenci seviyesine inilmelidir."

Ders kitabında konular ayrıntılı verilmemeli daha çok konular maddeleştirilerek ifade edilmelidir. Konu veya ünite sonlarında özet kısmı yer almalı ve etkinliklere daha fazla zaman ayrılmalıdır.

Sosyal bilgiler öğretmenlerinin ikisi değerlendirme sorularının artması gerektiğini, ikisi konulara ait liste ve tablolar eklenmesi gerektiği ve yine öğretmenlerden ikisi eski ve yeni olayların karşılaştırmalı olarak verilmesi gerektiği şeklinde görüşlerini beyan etmişlerdir. Öğretmenlerden biri ise ders kitabının konuların bölündügü fasiküller halinde hazırlanması gerektiğini ifade etmiştir. Bu durumla ilgili öğretmenler şu ifadelere yer vermişlerdir.

Ö6: "Konulara yönelik sözlük hazırlanmalıdır. Bol sorulu değerlendirme soruları olmalı ve ayrica eba soruları test kitabı olarak dağıtılmahıdır."

$\ddot{O}_{7}:$ "Öğrencilerin konuları pekiştirecekleri soru sayısı arttırılmalıdır. Kazanımları ölçmeye yönelik soru bankası kitapla birlikte öğrencilere dă̆ıtılmalıdır."

Ö8: "Ders kitabının sözlük kısmı daha geniş tutulmalıdır. Aktarılan konularm günümüz Türkiye'sine etkisi, işleyişindeki değiş̧ikler günümüzden örnekler verilerek daha kalıcı öğrenme să̆lanabilir."

Sosyal bilgiler öğretmenleri T.C. İnkılap Tarihi ve Atatürkçülük ders kitabında konu sonlarına veya ünite sonlarına sözlük eklenmeli, konu sonlarında daha çok sorular olmalı ve ayrıca soru kitapları basılarak ders kitapları ile beraber öğrencilere dağıtılması hususlarını belirtmişlerdir. 


\section{Sonuç, Tartışma ve Öneriler}

Bu araştırmanın amacı, 2016-2017 eğitim-öğretim yılında okutulan T.C. İnkılap Tarihi ve Atatürkçülük ders kitabına yönelik sosyal bilgiler öğretmenlerinin görüşlerini belirlemektir. Sosyal bilgiler öğretmenlerinden alınan görüşler doğrultusunda değerlendirmelerde bulunulmuştur.

Sosyal bilgiler öğretmenleri konuların ayrıntılı anlatıldığını, gerekli bilgiler fazlasıyla verildiğini ama kavramsal şemalar oluşturulmadığını belirterek bundan dolayı da konuların öğrencilere zor geldiğini ifade etmiştir. Ders kitabındaki birçok konunun gereksiz uzunlukta anlatıldığını ifade eden sosyal bilgiler öğretmenleri konularda ayrıntıya girilmesinden dolayı öğrencinin sıkıldığını belirtmişlerdir. Öğretmen görüşlerine göre, ders kitaplarında konular uzun olmamalı ve kitaplarda gereksiz detaylardan kaçınılmalıdır.

Alanyazın incelendiğinde yapılan çeşitli araştırmalarda benzer öğretmen görüşlerinin yer aldığ1 görülmektedir (Esen, 2017; Kulantaş, 2007; Önal ve Kaya, 2006; Öcal ve Yiğittir, 2007; Yıldırım, 2014). Yıldırım (2014) sosyal bilgiler etkinlik kitapları üzerine yaptığı araştırmada öğretmen görüşlerine başvurmuştur. Yapılan araştırmada öğretmenlerin görüşleri neticesinde kitapta ayrıntıların çok fazla olduğu, öğrencilerin ayrıntılarla çok boğuşmak istemediklerini, bu yüzden de etkinlikleri isteksizce yaptıklarını belirtmişlerdir. Öğretmen görüşlerinden yola çıkarak çalışma kitaplarının öğrencileri çok sıktığı bunun için kitabın daha sevebilecek hale getirilmesi gerektiği araştırma neticesinde ortaya konulmuştur. Kulantaş (2007) "4 ve 5. Sinıf Sosyal Bilgiler Dersinde Kullanılan Öğrenci Ders ve Çalışma Kitapları ile Öğretmen Kılavuz Kitaplarının, Öğretmen, Öğrenci ve Veli Görüşlerine Göre Değerlendirilmesi" adlı çalışmasında öğretmenler ders kitaplarında bulunan metinleri çok uzun buldukları sonucuna varmıştır. Bununla birlikte cümlelerin uzun olmasının da anlamayı daha güç hale getirdiğini belirtmişlerdir. Öcal ve Yiğittir (2007) "İlköğretim Sosyal Bilgiler Kitaplarının Öğretmen Görüşlerine Değerlendirilmesi (Kırıkkale Örneği)" adlı çalışmasında, öğretmenlerin büyük çoğunluğu ders kitaplarında ayrıntıya fazla girildiğini ve ders kitaplarında fazla gereksiz bilgi verildiğine dair görüş belirtmişlerdir. Esen (2017) yaptığ1 araştırmada öğretmen görüşleri doğrultusunda 7. sınıf sosyal bilgiler ders kitabının öne çıkan güçlüğü olarak gereksiz bilg- 
ilerin olması sonucuna varmıştır. Önal ve Kaya (2006) “Sosyal Bilgiler Ders Kitaplarının (4. ve 5. Sinıf) Değerlendirilmesi" adlı çalışmasında görsel unsurlar ve içeriklerin niteliğinin arttırılması gerektiğini belirtmiştir.

Araştırmamızda sosyal bilgiler öğretmenlerine yöneltilen sorular doğrultusunda, ders kitabında yer alan görsellerin öğrencilerin dikkatini çekecek nitelikte olduğunu ancak sözel anlatımın öğrencilere fazla geldiğini belirtmişlerdir. Öğretmenler özellikle haftalık ders saatinin arttırılmasını istemişlerdir. Bu görüşlere paralel olarak Yıldırım (2014) öğretmenlerin 3 saat olan dersin 2 saate düşürülmesi ve kitabın buna uygun olmaması nedeniyle zaman sıkıntılarının çok olduğunu ifade ettiklerini araştırmasının neticesinde ifade etmiştir. Araştırmasının sonucunda, öğretmenlerin çalışma kitabının sınıfta işlenmesinin mümkün olmadığını belirtmişlerdir. Öğretmenler çoğu zaman etkinliklerin yapılıp yapılmadığını kontrol edemediklerini ifade etmişlerdir. Bu da araştırmamızın Yıldırım (2014) “T.C. Inkılap Tarihi ve Atatürkçülük Dersi Öğrenci Çalışma Kitabı Hakkında Sosyal Bilgiler Öğretmenlerinin Görüşleri" adlı çalışmasında yer alan öğretmen görüşleri ile paralellik gösterdiğini ortaya koymaktadir.

Araştırmamız sonucunda öğretmenlerin çoğu görsellerin yetersiz olduğunu ifade etmiştir. Bunun yanı sıra öğretmenler ders kitabında bulunan görsellerin öğrencilerin dikkatini çekmekte de yetersiz olduğunu belirtmiştir. Alanyazın incelendiğinde yapılan çeşitli araştırmalarda benzer öğretmen görüşlerinin yer aldığ görülmektedir (Çakır, 2006; Dündar, 1995; Esen 2017). Çakır (2006) ilköğretim dördüncü sınıf ders kitaplarının görsel özellikleri ile ilgili olarak öğretmen görüşleri doğrultusunda kitapta bulunan grafik, şekil, fotoğraf vb. görsel unsurların yeterli olmadığı sonucuna ulaşmıştır. Dündar (1995) araştırmasında ders kitaplarının görsel öğelerinin öğrenci düzeyine uygun olmadığını tespit etmiştir. Esen (2017) araştırmasında öğretmenlerin çoğunluğu mevcut ders kitaplarının teknik tasarım açısından değişmesi gerektiğini belirtmişlerdir. Araştırmasının sonucunda ise ders kitaplarında kullanılan resim, fotoğraf, grafik ve çizelgelerin daha da geliştirilmesinin gerektiği ifade edilmiştir. Sonuç olarak ders kitaplarındaki görsel öğelerin yetersiz olduğu ifade edilebilir. Buna karşın araştırmamızın sonucu Çetin'in (2008) yaptığı araştırmanın sonucu ile çelişmektedir. 
Araştırmamızda sosyal bilgiler öğretmenleri T.C. İnkılap Tarihi ve Atatürkçülük ders kitabının kullanımı ile ilgili olarak içeriğin yoğun olması, metinlerin uzun olması ve konuların açık, net ve anlaşılır ifade edilmeyişini ders kitabının öne çıkan güçlükleri olarak belirtmişlerdir. Yine sosyal bilgiler öğretmenleri T.C. İnkılap Tarihi ve Atatürkçülük ders kitabında görsellerin az olması, özet bilgilerin olmaması, yeterli sorunun sorulmadığını da ders kitabının eksiklikleri olarak belirtmişlerdir. Ayrıca ders kitabındaki konuların ve görsellerin yeterli olmadığını da ifade etmişlerdir. Alanyazın incelendiğinde yapılan çeşitli araştırmalarda benzer öğretmen görüşlerinin yer aldığı görülmektedir (Alleman ve Brophy, 1997; Kurtulmuş, 2010). Araştırmamız Kurtulmuş'un (2010) çalışması ile paralellik göstermektedir. Alleman ve Brophy (1997) sosyal bilgiler ders kitaplarındaki metinlere yönelik hazırladıkları anketi öğretmenlere uygulamışlardır. Araştırma sonucunda kitapta bulunan metinlerin sosyal bilgiler öğretimi için faydalı olduğu ancak daha kısa ve anlatımın daha sade olması gerektiği tavsiye edilmiştir.

Ayrıca araştırmamız ile sosyal bilgiler öğretmenlerinin görüşleri doğrultusunda önemli noktaların farklı renklerle, şekillerle ve uyarılarla belirtilmesi gerektiği sonucuna varılmıştır. Benzer şekilde Kulantaş (2007) çalışmasında ders kitabındaki anahtar kavram ve ilkelerin vurgulanmasının yeterince dikkat çekici olmadığı sonucuna ulaşmıştır.

Özetle, sosyal bilgiler öğretmenlerinin görüşleri doğrultusunda ders kitabının daha faydalı olması için konuların gereksiz ayrıntılardan kaçınılarak verilmesi gerektiği, sayfaların paragraflara boğulmaması ve önemli noktaların farklı renklerle, şekillerle ve uyarılarla belirtilmesi gerektiği şeklinde önerilerde bulunulabilir. Öğretmen görüşlerinin tamamı göz önüne alındığında ders kitaplarının görsel olarak zenginleştirmesi gerektiği de ifade edilebilir.

Öğretmen görüşleri dikkate alındığında şu önerilerde bulunulabilir:

- T.C. İnkılap Tarihi ve Atatürkçülük ders kitapları hazırlanırken fiziksel ve görsel açıdan geliştirilip öğrencinin dikkatini çekecek şekilde resim, grafik ve tablolar yeterince verilmelidir.

- Konu aralarında öğrencinin dikkatini çekecek not kutucuklarına yer verilmelidir. 
- Ders kitapları hazırlanırken öğrencinin dikkatini çekecek şifreleme ve kodlamalar kullanılarak öğrencinin zihninin konuya odaklanması sağlanmalıdır.

- Ders kitabında öğrencileri sıkmayacak şekilde paragraflara çok fazla yer verilmeden daha kısa içeriğe yer verilmelidir.

- Ders kitabında görseller arttırılmalıdır. Kullanılan görseller daha canlı ve güncel olmalıdır.

- Ünite sonlarına ünite özetleri eklenmelidir.

- Ünite sonu sözlüklere yer verilmelidir.

- Ders kitabı hazırlanırken eski ve yeni olaylar karşılaştırmalı olarak işlenip günümüzle bağlantılı şekilde ele alınmalıdır.

- Ders kitabında yer alan ölçme ve değerlendirme soruları arttırılmalıdır.

- Ders kitabı fasiküller şeklinde hazırlanmalıdır. 


\title{
EXTENDED ABSTRACT
}

\section{Evaluation of Social Studies Teachers' Visions Related the 8th Grade Turkish Republic History of Revolution and Atatürkism Course Book}

\author{
* \\ Özkan Ginesar - Cemal Güven \\ Ministry of National Education - Necmettin Erbakan University
}

It is assumed that the history of textbooks dates back to $4000 \mathrm{BC}$. Textbooks having such an old history have showed change and development according to the social, cultural and technological needs of the society from past to present (Çakır U. , 2006). Textbooks prepared to provide knowledge and skills to students who are transferred a particular curriculum are the oldest and most important teaching tools (Uzuner, Aktaş, \& Albayrak, 2010).

Textbooks are one of the most important information tools that students and teachers deal directly with in today's technology and information age. Textbooks are the most frequently used tools for teachers and students in education period. Textbooks still play an important role in today's technology age, as well (Çakır U. , 2006).

Course books in Turkey are a basic information source and the one of the most used teaching materials (Kılıç ve Seven, 2002). Course books allow for teachers to teach a lesson more systematically. Students find opportunity to review what teacher tell wherever and whenever they want thanks to course books (Küçükahmet, 2001). In addition, course books are important education factor helping and leading to both teacher and student throughout education (Kılıç ve Seven, 2002).

Considering that textbooks play the most important role in the development of cognitive, affective and psychomotor skills, the quality of primary school textbooks should be given great importance. Because a good education takes place with a good textbook (Uzuner, Aktas, \& Albayrak, 2010). Considering the contributions to education, the importance of process for preparation period of textbooks has increased. 
In this research, it was aimed at receiving opinion from social studies teacher about outstanding difficulties and deficiencies of secondary school 8th grade Turkish Republic History Of Revolution And Ataturkism course book, whether subjects and visuals are enough in course book, and what can be done for it to be more useful. It was evaluated and made suggestions in the direction of received teacher comments.

\section{The Objective of the Research}

The objective of this research is to evaluate teacher comments for the purpose of defining difficulties and deficiencies of 8th grade Turkish Republic History of Revolution and Ataturkism course book that is taught in 2016-2017 education year, and bringing course book to more functional state. It was included to teacher and student comments to dedicate course book to students as better.

\section{Method}

A qualitative research technique was used in this study. Data were collected using semi-structured interview form developed by researcher. Interviews were performed with 20 teachers working Kutahya city and its counties. Data were analyzed with content analysis method. Content analysis can be expressed as evaluation of data resembling each other by gathering around specific concepts and themes in the way that reader can understand. Categories are created while document is investigated. Researcher makes content analysis by creating interrelated cod list (matrix) and applying a range of codes to qualitative data (Ekiz, 2013).

In the interviews for the purposing to consider 8th grade the Republic of Turkey textbook, semi-structured interview form was developed by the researcher by considering interview forms used previous interviews for the same purpose.

\section{Data Collecting Tools}

A semi-structured interview form was used for the purposing of determining teachers' opinions. In the semi-structured interview form, the 
researcher prepares questions before starting the interview. On the other hand, it can rearrange the questions prepared by looking at the conditions or provide some flexibility by looking at individuals and questions (Çepni, 2014).

\section{Study Group of the Research}

The study group of the study consists of 20 teachers working in the center and districts of Kütahya. In the selection of the sampling, maximum diversity sampling from purposeful sampling methods was used. The diversity of individuals reflects the maximum degree of research for this research in this sampling method (Yıldırım \& Şimşek, 2016). Teachers from the Kutahya city center and countryside were selected. Intervies form was applied by meeting face to face interview. Teacher interviews also were volunteer basis.

\section{The Conclusion, Argument and Suggestions}

Social studies teachers stated that the subjects were explained in detail, the necessary information was given more, but the conceptual schemes were not created and therefore the subjects were difficult for the students. Social studies teachers, who stated that many subjects in the textbook were told unnecessarily, stated that the students were bored because of the details. According to the teachers' opinions, textbooks should not be long and the unnecessary details should be avoided.

When the literature is investigated, it is seen that similar teacher views are included in various researches conducted (Esen, 2017; Kulantaş, 2007; Önal and Kaya, 2006; Öcal and Yiğittir, 2007; Yıldırım, 2014). Yildirım (2014) consulted to the views of teachers in his research studied on social studies activity books. As a result of the opinions of the teachers in the study, the details of the book are very high, students do not want to struggle with details, so they stated that they do reluctantly activities. Based on the opinions of the teachers, it was found out that the study books were too bothered for the students and that the book should be made more lovable. 
As a result of this study, most of teachers stated that visuals are inadequate. Besides this, teachers specified that visuals are also inadequate to remark students. When body of literature was investigated, it was seen that similar teacher's comments are located in various performed studies (Çakır, 2006; Dündar, 1995; Esen 2017). As a result, it can be expressed that visual elements are inadequate in course books.

In the consequence of study, social studies teachers specified that subjects are told in depth and were given exceedingly but conceptual schemes weren't created. When body of literature was investigated, it was seen that similar teacher's comments are located in various performed studies (Esen, 2017; Kulantaş, 2007; Önal ve Kaya, 2006; Öcal ve Yiğittir, 2007; Yıldırım, 2014). Based on teacher's comments, we can state that subjects in the book shouldn't been told long and it should be required to give short abstract information.

In conclusion, it is required that subjects of course book are told as short and brief, visuality of course book is increased, pages are not choked to paraphs, and important points are specified with different colors, shapes and warnings.

\section{Kaynakça/References}

Alleman, J. ve B., Jere. (1997). Literacy approach to teaching social studies. Education Research Reports http://www.educ.msu.edu/reports/edresearch/1997/ october1.htm

Ceylan, E., ve Yiğit, B. (2004). Konu alanı ders kitabı incelemesi (2. b.). Ankara: Anı Yayıncllı.

Çakır, A. (2006). İlköğretim dördüncü sınıf matematik ders kitaplarn ile ilgili öğretmen görüşleri. Yüksek Lisans Tezi. Eskişehir Osmangazi Üniveristesi, Sosyal Bilimler Enstitüsü, Eskişehir.

Çakır, U. (2006). Türkiye Cumhuriyeti inkılap tarihi ve Atatürkçülük ders kitabı görsellerinin bazı özelllikler açısından incelenmesi. Ihlara Ĕ̆itim Araştırmaları Dergisi, 1(1), 01-13.

Çepni, S. (2014). Araştırma ve proje çalışmalarına giriş (7. b.). Trabzon: Celepler Matbaacilik. 
Çetin, A. (2008). 6. sınıf yeni sosyal bilgiler ders kitabınm (2005) öğretmen görüşlerine göre değerlendirilmesi. Yüksek Lisans Tezi. Afyonkarahisar Kocatepe Üniversitesi, Sosyal Bilimler Enstitüsü, Afyonkrahisar.

Duman, T., ve Çakmak, M. (2003). Ders kitabının nitelikleri. L. Küçükahmet içinde, Konu Alanı Ders Kitabı İnceleme Kılavuzu (s. 16-34). Ankara: Nobel Yayınları.

Dündar, A. (1995). Ortaokul temel ders kitaplarının eğitsel ve grafiksel açıdan değerlendirilmesi. Yüksek Lisans Tezi. Gazi Üniversitesi, Sosyal Bilimler Enstitüsü, Ankara.

Ekiz, D. (2013). Bilimsel araştırma yöntemleri (3. b.). Ankara: An1 Yayincilik.

Esen, S. (2017). 7. sinıf sosyal bilgiler ders kitabının öğretmen görüşlerine göre incelenmesi. Yüksek Lisans Tezi. Balıkesir Üniversitesi, Sosyal Bilimler Enstitüsü , Balıkesir.

Ginesar, Ö. (2017). 8. sınıf T.C. inkılap tarihi ve Atatürkçülük ders kitabına yönelik sosyal bilgiler öğretmenlerinin algı ve tutumlarmın belirlenmesi. Yüksek Lisans Tezi. NEÜ Eğitim Bilimleri Enstitüsü, Konya.

Ginesar, Ö., ve Güven, C. (2017, Kasım 24-25). Ortaokul T.C. ink1lap tarihi ve Atatürkçülük ders kitabının öğretmen görüşlerine göre değerlendirilmesi. 3'üncü Uluslararası Eğitim, Uzaktan Eğitim ve Ĕgitim Teknolojileri Kongresi. Antalya.

Kesici, Ş. (2007). Şube rehber öğretmenlerinin görüşlerine göre 6., 7. ve 8. sınıf öğrencilerinin rehberlik ve danışma ihtiyaçları. Selçuk Üniversitesi Sosyal Bilimler Enstitüsü Dergisi, 1(17), 365-383.

Kılıç, A., ve Seven, S. (2002). Konu alanı ders kitabı incelemesi (1. b.). Ankara: Pegem Yayınevi.

Kulantaş, N. (2007). 4. ve 5. sinff sosyal bilgiler dersinde kullanilan ders ve öğrenci çalışma kitapları ile öğretmen kılavuz kitaplarının, öğretmen, öğrenci ve veli görüşlerine göre değerlendirilmesi. Doktora Tezi. Gazi Üniversitesi, Eğitim Bilimleri Enstitüsü, Ankara.

Milli Eğitim Bakanlığı. (2006). Türkiye Cumhuriyeti inkılap tarihi ve Atatürkçülük dersi 8. sınıf programı. Ankara: MEB, Talim Terbiye Kurulu Başkanlığı. 
Öcal, A., ve Yiğittir, S. (2007). İlköğretim sosyal bilgiler ders kitaplarının öğretmen görüşlerine göre değerlendirilmesi (Kırıkkale örneği). Ahi Evran Üniversitesi Kırşehir Ĕ̆itim Fakültesi Dergisi (KEFAD), 8(1), 51-61.

Önal, H., ve Kaya, N. (2006). Sosyal bilgiler ders kitaplarının (4 ve 5. sinıf) değerlendirilmesi. Balkesir Üniversitesi Sosyal Bilimler Enstitüsü, 9(16), 21-39.

Şimşek, A., ve Güler, M. (2013). Öğretmen ve öğretmen adayı görüşlerine göre lise Atatürk ilkeleri ve inkılap tarihi dersinin öğretiminde yaşanan sorunlar ve çözüm önerileri. Adıyaman Üniversitesi Sosyal Bilimler Enstitüsü Dergisi, 543-574.

Tüysüz, S. (2016). İlköğretim 8. sinıf Türkiye Cumhuriyeti inkılap tarihi ve Atatürkçülük ders kitabı. Ankara: Tuna Matbaacılık.

Tüysüz, S. (2016). İlköğretim 8. sinıf Türkiye Cumhuriyeti inkılap tarihi ve Atatürkçülük öğrenci çalışma kitabı. Ankara: Tuna Matbaacılık.

Tüysüz, S. (2016). İlköğretim 8. sinıf Türkiye Cumhuriyeti inkılap tarihi ve Atatürkçülük öğretmen kılavuz kitabı. Ankara: Tuna Matbaacılık.

Uzuner, S., Aktaş, E., ve Albayrak, L. (2010). Türkçe 6, 7. ve 8. sınıf ders kitaplarının görseller (illüstrasyonlar) açısından değerlendirilmesi. Türk Bilimi Araştırmaları Dergisi, 27, 721-733.

Wakefield, J. F. (2006). Textbook usage in the United States: The case of US history. Online Submission

Yıldırım, A., ve Şimşek, H. (2016). Sosyal bilimlerde nitel araştırma yöntemleri (10. b.). Ankara: Anı Yayınları.

Yıldırım, F. (2014). 8. sinıf T.C. inkılap tarihi ve Atatürkçülük dersi öğrenci çalışma kitabı hakkında sosyal bilgiler öğretmenlerinin görüşlerinin değerlendirilmesi. Yüksek Lisans Tezi. Gaziosmanpaşa Üniversitesi, Eğitim Bilimleri Enstitüsü,Tokat

\section{Kaynakça Bilgisi / Citation Information}

Ginesar, Ö ve Güven C. (2018). Sosyal bilgiler öğretmenlerinin 8. sınnf T.C. inkilap tarihi ve Atatürkçülük ders kitabıyla ilgili görüşlerinin değerlendirilmesi. OPUS-Uluslararası Toplum Araştırmaları Dergisi, 9(16), 1017-1041. DOI: 10.26466/opus.477153 